\title{
Early Somatic Embryogenesis in Heliconia chartacea Lane ex Barreiros cv. Sexy Pink Ovary Section Explants
}

\author{
Cláudia Ulisses ${ }^{1 *}$, Terezinha Rangel Camara ${ }^{2}$, Lilia Willadino ${ }^{2}$, Cynthia Cavalcanti de \\ Albuquerque $^{3}$ and Júlio Zoé de Brito ${ }^{4}$ \\ ${ }^{1}$ Universidade Federal Rural de Pernambuco; Unidade Acadêmica de Garanhuns; Av. Bom Pastor s/n; 55.296-901; \\ Garanhuns - PE - Brasil. ${ }^{2}$ Universidade Federal Rural de Pernambuco; Recife - PE - Brasil. ${ }^{3}$ Universidade \\ Estadual do Rio Grande do Norte; Mossoró - RN - Brasil. ${ }^{4}$ Centro de Tecnologias Estratégicas do Nordeste; Recife \\ - PE - Brasil
}

\begin{abstract}
The present work evaluated the development of embryogenic callus from transversal ovary sections. The experiments were carried out under two experimental regimes using combinations of IAA $(0 ; 5.71 ; 8.56 ; 11.42$; $14.27 \mu M)$ and $2,4-D(0 ; 13.57 ; 18.10 ; 22.62 \mu M)$ or combinations of $2,4-D$ with $B A(0 ; 4.43 ; 6.65 ; 8.87 ; 11.09 \mu M)$. Assessments were made of anatomical aspects of the callus and for the presence of embryogenic structures using cytochemical and histological analyses and stereomicroscopic and scanning electronic microscopic observations. Treatments with 2,4-D and IAA produced friable calluses demonstrating cellular acquisition of morphogenetic competence as well as the formation of pro-embryogenic sectors. The expression of embryogenic program could be observed, with proembryogenic cell clusters developing into globular embryos. These results offer the possibility of using new types of explants for culturing helicons that avoid the growth of endophytic bacteria.
\end{abstract}

Key words: Callogenesis, growth regulator, histology, scanning electron microscopy

\section{INTRODUCTION}

Ornamental tropical plants have attracted the interest of international flower markets due to their beauty, exotic nature, and the post-harvest persistence of their inflorescences. Brazil has a large contingent of native plant species that fit these requirements, with the Sexy Pink cultivar of Heliconia chartacea Lane ex Barreiros being among the most valued for exportation.

Helicons have a subterraneous rhizome from which new buds are commonly removed for propagation (Castro, 1995), although this vegetative propagation system yields reduced number of plants and offers serious risks of pest and disease dissemination. Micropropagation has emerged as an important alternative for providing large-scale production of helicon plants with high standards of quality, but the micropropagation of helicons via shoot tips presents problems linked to endophytic contamination that can limit explant development (Nathan et al., 1992; Atehortua et al., 1999; Dias and Rodrigues, 2001; Rodrigues, 2005) so that the use of floral explants may represent a viable alternative (Atehortua et al., 1999).

Plant genetics and biotechnology is highly dependent on the use of in vitro culture techniques, and among the various systems available, somatic embryogenesis offers the opportunity for the production of true-to-type plants by clonal

\footnotetext{
*Author for correspondence: claudia@nlink.com.br
} 
propagation and is a useful tool for basic research on totipotency and the fundamental processes of plant morphogenesis (Gaj, 2004).

Ovary sections were used in the present work to establish in vitro cultures of $\mathrm{H}$. chartacea Lane ex Barreiros cv. Sexy Pink without endophytic contamination and to evaluate the induction and development of embryogenic callus.

\section{MATERIALS AND METHODS}

The ovaries from immature inflorescences of the Sexy Pink cultivar of Heliconia chartacea with one closed and four open bracts were used as explant sources. These explants were washed with pure detergent, rinsed with running water, immersed in alcohol (70\%) for one minute, followed by two immersions in calcium hypochlorite solution (a $3 \%$ solution for 20 minutes and another at $1.5 \%$ for 15 minutes, both containing three drops of $20 \%$ Tween) and finally submitted to three rinses with sterile distilled water to eliminate the disinfecting agents. Cross and transversal sections of the ovaries were then made, measuring approximately $0.7 \mathrm{~cm}$ in diameter and $0.2 \mathrm{~cm}$ in thickness, and these were inoculated into test tubes $(2.5 \times 15 \mathrm{~cm})$ containing $10 \mathrm{~mL}$ of $\mathrm{MS}$ culture medium (Murashige and Skoog, 1962).

Culture medium was prepared containing either 0; $13.57 ; 18.10$ or $22.62 \mu \mathrm{M} 2,4-\mathrm{D}$ with either 0 ; $5.71 ; 8.56 ; 11.42$ or $14.27 \mu \mathrm{M}$ IAA, in accordance with Valencia and Atehortua (1999). In a second series of assays, these same varying concentrations of 2.4-D were combined with $0 ; 4.43 ; 6.65 ; 8.87$ or $11.09 \mu \mathrm{M}$ BA. Both assays were conducted using 10 replicates per treatment. The basic MS medium was supplemented in all cases with 30 g. $\mathrm{L}^{-1}$ sucrose, 0.2 g.L. $\mathrm{L}^{-1}$ glycine, and $2 \mathrm{~g} . \mathrm{L}^{-1}$ phytagel. The $\mathrm{pH}$ was adjusted to 5.8 before autoclaving at 121 ${ }^{\circ} \mathrm{C}$ for 20 minutes. All inoculated material was kept in the dark for 90 days at $25^{ \pm} 2{ }^{\circ} \mathrm{C}$.

Evaluations of callus material were undertaken at 30,60 and 90 days after inoculation with the aid of a stereomicroscope. The induction frequency $(\%)$ of the callus was calculated by: (the number of explants forming calluses/total number of explants) x 100. A non-parametric statistical test was applied to the induction frequency of calluses based on the Qui-square distribution, and $\operatorname{arcsen} \sqrt{\%}$ transformed data was compared by Tukey's test.
Calluses that presented nodular surfaces and a yellow coloration were selected after 90 days in the induction medium and samples were prepared for cytochemical and histological analyses. The remaining calluses were transferred to MS medium supplemented with 30 g. $\mathrm{L}^{-1}$ of sucrose, 2 g. $\mathrm{L}^{-1}$ phytagel, and $4.43 \mu \mathrm{M} \mathrm{BA}$ in order to induce a somatic conversion of the embryos into plants. The calluses were kept for 60 days at $25^{ \pm} 2^{\circ} \mathrm{C}$ with a $16 \mathrm{hr}$ photoperiod at a light intensity of 50 $\mu$ mols. $\mathrm{m}^{2} . \mathrm{s}^{-1}$.

Callus derived from the induction medium were stained with Evans blue $(0.1 \%)$ and acetic carmine (2\%) to visualize the somatic pro-embryos, as described by Guerra et al. (1999) and were examined and photographed using an optical microscope (Carl Zeiss).

Callus that presented nodular structures on their surfaces were selected for histological studies, and were dehydrated, infiltrated using automatic histotechnical equipment, and embedded in paraffin wax on a Tissue-tec apparatus. Semi-thin $(4-6 \mu \mathrm{m})$ sections were cut on a horizontal rotary microtome (Slee Technik) for general examination, and then stained with hematoxylin and eosin (Johansen, 1940).

Samples to be viewed by scanning electron microscopy were fixed in $3 \%$ glutaraldehyde, dehydrated in ethylic alcohol series (50, 70, 90 and $100 \%$ ), dried using a critical point $\mathrm{CO}_{2}$ dryer, and then gold coated $\left(300 \mathrm{~A}^{\circ}\right)$. A scanning electron microscope (Hitachi S800-10kV) was used for examination and photographing the callus material.

\section{RESULTS AND DISCUSSION}

Ovary sections were observed to swell after 30 and 60 days of treatment with IAA+2,4-D and $\mathrm{BA}+2,4-\mathrm{D}$, which is characteristic of the callusinduction phase in which the explant swells and then develops into a friable callus (Yadav and Rajam, 1998). Ninety days after inoculation, the explants growing in IAA+2,4-D demonstrated higher frequencies of callus formation than explants in BA+2,4-D (Table 1). Yellowish callus 5-7 $\mathrm{mm}$ in diameter were obtained in treatments with IAA and 2,4-D. These callus showed smooth, compact, globular embryogenic structures that were easily distinguishable from the rest of callus. 
These globular embryogenic structures were quite numerous and covered most of surface of the callus that was not in direct contact with the medium (Fig. 1A). Similar results have been reported for coconut (Sáenz et al., 2006) and papaya sections (Almeida et al., 2001).

Embryogenic callus can be obtained from floral shoots of Heliconia stricta after incubation in MS medium supplemented with 13.57 to $22.62 \mu \mathrm{M} 2$,4$\mathrm{D}$ and 5.71 to $14.27 \mu \mathrm{M}$ IAA for four to six months (Valencia and Atehortua, 1999). This induction period is longer than that seen in the present work, in which the development of embryogenic callus and somatic embryos were seen after only three months of in vitro cultivation. The results of this simultaneous use of two auxin sources to induce embryogenic callus was quite different from that reported by other authors (Kurten et al., 1990; Mathew and Philip, 2003) who used combinations of auxins and cytokinins. The callus formed in treatments with BA and 2,4-D appeared whitish and aqueous. A majority of the BA treatments demonstrated harmful effect on callus development in the Sexy Pink cultivar. Similar results were reported by Martini et al. (2001), who observed an inhibiting action of the BA on induction and proliferation, in orchid (Gongora quinquenervis) callus. According to Williams and Maheswaran (1986), BA acts strongly in inducing cell polarity and favors the differentiation process of embryogenic callus material.

No callus development was observed without auxin treatment (control). In the treatment without 2,4-D but with $5.71 \mu \mathrm{M}$ IAA, a low frequency of callus formation was seen that was inhibited by increasing IAA levels (Table 1).

$2,4-\mathrm{D}$ is capable of setting off processes of dedifferentiation (indirect models) and redifferentiation (direct models), thus altering cellular determination and endowing new competencies to responsive cells present in the explants (Nowak and Shulaev, 2003). The pro-embryogenic cellular mass cultivated in the presence of auxin is able to synthesize the proteins necessary for forming a globular-stage embryo (Zimmerman, 1993).

Proteins are one of the molecular bases of the embryogenic cells formation (Liu et al., 2006).

Roots were observed to grow from pseudostem fine sections of Heliconia psittacorum when these were cultivated in the presence of $10 \mu \mathrm{M}$ of $2,4-\mathrm{D}$, whereas callus formation occurred only at higher concentrations (40 and $80 \mu \mathrm{M})$ (Goh et al.,1995). It has been demonstrated that 2,4-D is more effective than IAA in promoting embryogenic callus development in Feijoa sellowiana, Carya illinoinensis, and Fragaria sp. (Cruz et al., 1990; Rodriguez and Wetzstein, 1998; Flores et al., 2003). On the other hand, IAA specifically induced the development of somatic embryos of Paulownia tomentosa (Radojevic, 1979). The different results that are induced by different auxin sources are apparently related to the genetic constitution of the plant material ( $\mathrm{Hu}$ and Ferreira, 1998; Sakhanokho et al., 2005).

The callus in most treatments with IAA+2,4-D demonstrated cells with reduced sizes, nucleolus not clearly defined, dense cytoplasmic content and intense metabolic activity (as indicated by the deep red color observed with added acetic carmine, Fig. 1B). Cells that demonstrated these characteristics were considered embryogenic cells (Durzan, 1988; Mathew and Philip, 2003; Kim et al., 2003; Sáenz et al., 2006) and staining with acetic carmine indicated the presence of reserve substances that would favor tissue development (Guerra et al., 1999).

The combination of IAA and 2,4-D also promoted the development of yellowish nodules, especially in the treatments with $8.56 \mu \mathrm{M}$ IAA plus 13.57 $\mu \mathrm{M}$ 2,4-D; $11.42 \mu \mathrm{M}$ IAA plus $22.62 \mu \mathrm{M}$ 2,4-D; and $14.27 \mu \mathrm{M}$ IAA plus $22.62 \mu \mathrm{M}$ 2,4-D. Histological analyses of this callus material revealed heavily stained cells located on the surface of the callus. Transverse sections showed that these structures consisted of meristematic cells surrounded by a protoderm. Some globular embryogenic structures became larger, while others seemed to fuse and acquire an elongated appearance. The inner tissue of the callus consisted mostly of parenchyma cells and vascularized zones (Fig. 1C). Hervé et al. (2001) likewise observed the presence of a protuberance on the superficial layer of the callus in Eucalyptus gunnii Hook, which they interpreted as a region of pro-embryogenic cells. 
Table 1 - Induction frequencies of callus formation from ovary sections of $H$. chartacea Lane ex Barreiros cv. Sexy Pink after 90 days in MS medium with different combinations of IAA+2,4-D or BA+2,4D $(\mu \mathrm{M})$.

\begin{tabular}{cccc}
\hline $\begin{array}{c}\text { Treatments } \\
(\mu \mathrm{M})\end{array}$ & $\begin{array}{c}\text { Frequency of } \\
\text { formation callus }(\%)\end{array}$ & $\begin{array}{c}\text { Treatments } \\
(\mu \mathrm{M})\end{array}$ & $\begin{array}{c}\text { Frequency of formation } \\
\text { callus }(\%)\end{array}$ \\
\hline 0 IAA + $2,4-\mathrm{D}$ & $0 \mathrm{~b}$ & $0 \mathrm{BA}+02,4-\mathrm{D}$ & $0 \mathrm{~b}$ \\
0 IAA + 13.57 2,4-D & $100 \mathrm{a}$ & $0 \mathrm{BA}+13.572,4-\mathrm{D}$ & $100 \mathrm{a}$ \\
0 IAA + 18.10 2,4-D & $70 \mathrm{ab}$ & $0 \mathrm{BA}+18.102,4-\mathrm{D}$ & $100 \mathrm{a}$ \\
0 IAA + 22.62 2,4-D & $100 \mathrm{a}$ & $0 \mathrm{BA}+22.622,4-\mathrm{D}$ & $0 \mathrm{~b}$ \\
5.71 IAA + $2,4-\mathrm{D}$ & $30 \mathrm{ab}$ & $4.43 \mathrm{BA}+02,4-\mathrm{D}$ & $20 \mathrm{ab}$ \\
5.71 IAA + 13.57 2,4-D & $80 \mathrm{ab}$ & $4.43 \mathrm{BA}+13.572,4-\mathrm{D}$ & $40 \mathrm{ab}$ \\
5.71 IAA + 18.10 2,4-D & $100 \mathrm{a}$ & $4.43 \mathrm{BA}+18.102,4-\mathrm{D}$ & $100 \mathrm{a}$ \\
5.71 IAA + 22.62 2,4-D & $80 \mathrm{ab}$ & $4.43 \mathrm{BA}+22.622,4-\mathrm{D}$ & $20 \mathrm{bb}$ \\
8.56 IAA + $2,4-\mathrm{D}$ & $0 \mathrm{~b}$ & $6.65 \mathrm{BA}+02,4-\mathrm{D}$ & $0 \mathrm{~b}$ \\
8.56 IAA + 13.57 2,4-D & $60 \mathrm{ab}$ & $6.65 \mathrm{BA}+13.572,4-\mathrm{D}$ & $0 \mathrm{~b}$ \\
8.56 IAA + 18.10 2,4-D & $100 \mathrm{a}$ & $6.65 \mathrm{BA}+18.102,4-\mathrm{D}$ & $0 \mathrm{~b}$ \\
8.56 IAA + 22.62 2,4-D & $60 \mathrm{ab}$ & $6.65 \mathrm{BA}+22.622,4-\mathrm{D}$ & $20 \mathrm{ab}$ \\
11.42 IAA + $2,4-\mathrm{D}$ & $0 \mathrm{~b}$ & $8.87 \mathrm{BA}+02,4-\mathrm{D}$ & $0 \mathrm{~b}$ \\
11.42 IAA + 13.57 2,4-D & $100 \mathrm{a}$ & $8.87 \mathrm{BA}+13.572,4-\mathrm{D}$ & $20 \mathrm{ab}$
\end{tabular}

Averages followed by different letters on each column, differ among themselves at the $5 \%$ level of probability by the Tukey's Test.

Callus submitted to treatment with $8.56 \mu \mathrm{M}$ IAA plus $13.57 \mu \mathrm{M} 2,4-\mathrm{D}$ demonstrated the onset of organogenic processes, with the presence of a chlorophyll-bearing structures above the callus tissue. Although organogenic competence is usually regulated by cytokinins (Inoue et al., 2000; Rai and McComb, 2002), this structure did not continue organogenic development when transferred to growth medium with $4.43 \mu \mathrm{M} \mathrm{BA}$. Significant differences in in vitro organogenic responses have been observed when the mineral composition, vitamins or sugar sources of the medium are altered (Peres, 2002). Plant growth regulators, however, still remain the most critical components of the culture medium. Competence in organogenic processes can be understood as the ability to respond to the hormonal stimuli necessary for the induction organ development. The competence failure of a tissue might therefore reflect the absence of receptors (proteins) that interface with growth regulators to induce organogenic processes in those cells.

After the callus-induction phase, the yellowish friable callus demonstrated cellular acquisition of morphogenetic competence during which proembryogenic sectors were formed (Yadav and Rajam, 1998). The images obtained by scanning electron microscopy show embryogenic tissue with several pro-embryos (Fig. 1D) in the $14.27 \mu \mathrm{M}$ IAA plus $22.62 \mu \mathrm{M} 2,4-\mathrm{D}$ treatment. A close-up of this embryogenic tissue shows two spherical cells at the time of cytokinesis (Fig. 1E) and demonstrates how the daughter cells of the embryogenic tissue remain as a coherent tissue (Fig. 1F), like was observed by Sondahl et al. (1979) in coffee embryogenic callus. The expression of embryogenic program could subsequently be observed when the proembryogenic clusters developed into the first visible globular embryos (Yadav and Rajam, 1998). 

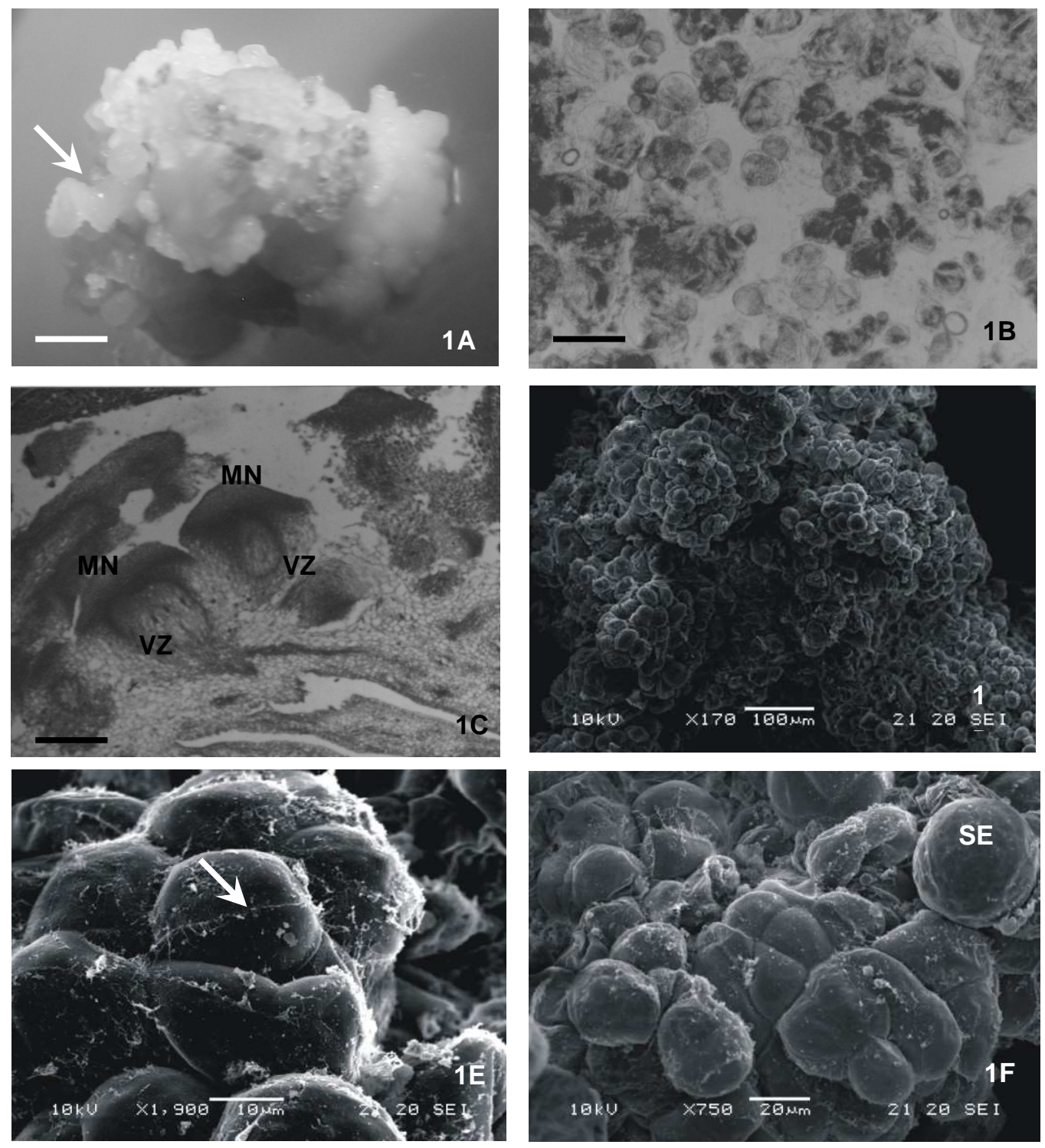

Figure 1 - General aspect of the callus with embryogenic cells, and histological sections of callus derived from transversal ovary sections of cv. Sexy Pink after 90 days of treatment with $14.27 \mu \mathrm{M}$ IAA plus $22.62 \mu \mathrm{M}$ 2,4-D in vitro culture: (1A) Somatic embryos on the surface of the callus (arrows) (Bar $=1.25 \mathrm{~mm})$; (1B) Pro-embryogenic cells with densely stained cytoplasm indicating high metabolic activity $(\mathrm{Bar}=1 \mu \mathrm{m})$; $(\mathbf{1 C})$ Cross-section of the callus showing meristematic nodules $(\mathrm{MN})$ and vascularized zones (VZ) $(\mathrm{Bar}=25 \mu \mathrm{m})$. (1D) General view of the grouping of pro-embryos in calluses as viewed using scanning electron microscopy (SEM); (1E) Close-up of embryogenic tissue shows two spherical cells at the time of cytokinesis (arrow) under SEM; (1F) Close-up (SEM) of a region with a cylindrical shaped somatic embryo (SE) demonstrating how the daughter cells of the embryogenic tissue remain as a coherent tissue. 
A cylindrical-shaped embryo in a more advanced stage than the globular phase is shown in Fig. 1F. Our results indicate that combinations of two sources of auxin (natural IAA and synthetic 2,4-D) are more efficient in inducing embryogenic calluses than combinations of auxin (2,4-D) and cytokinin (BA), and also confirmed the existence of embryogenic cells and the outstanding importance of auxins in embryogenic callus induction in the species under study.

High 2,4-D concentrations can affect somatic embryo development and plantlet regeneration. According to Franco et al. (2006), somatic embryo expression is possible when 2,4-D is suppressed or replaced by weaker auxins (such as NAA in low concentrations). However, in the present work, somatic embryos did not show any potential for conversion into plants when treated with BAP without 2,4-D. In spite of the high numbers of somatic embryos produced in many systems there was only a low or zero frequency of embryo conversion into plants. A number of different strategies were tested to stimulate embryo conversion and to improve the efficiency of plant regeneration, including the addition of gibberellic acid (Kim et al, 1997) or polyamines, especially spermine (Kevers et al., 2002).

To our knowledge, there have been no previous studies using explants from ovaries to induce somatic embryogenesis in helicons. These results indicate an alternative source of explants for in vitro culturing of helicons without any apparent contamination from endophytic bacteria. We were able to induce the expression of an embryogenic program in these explants in spite of the fact that the embryos failed to generate new plants.

\section{ACKNOWLEDGMENTS}

Authors would like to thank Prof. Isabelle Meunier from Universidade Federal Rural de Pernambuco (UFRPE) for her help with the statistical calculations; the Keizo Azami Immunopathology Laboratory (LIKA) for the analyses; and the Banco do Nordeste do Brasil (BNB) and Coordenação de Aperpeiçoamento Pessoal do Ensino Superior (CAPES) for their financial support of this work.

\section{RESUMO}

Este trabalho teve como objetivo avaliar a resposta de secções transversais de ovários e o desenvolvimento de calos embriogênicos. O experimento constou de dois ensaios. No primeiro avaliou-se combinações entre AIA $(0 ; 5.71 ; 8.56$; $11.42 ; 14.27 \mu \mathrm{M})$ e $2,4-\mathrm{D} \quad(0 ; 13.57 ; 18.10$; $22.62 \mu \mathrm{M})$ e no segundo avaliou-se as concentrações de 2,4-D supracitadas, combinadas com concentrações de BA $(0 ; 4.43 ; 6.65 ; 8.87$; $11.09 \mu \mathrm{M})$. Os calos formados foram avaliados quanto à presença de estruturas embriogênicas utilizando-se estereomicroscópio, microscópio eletrônico de varredura, além de análises citoquímicas e histológicas. Combinações entre 2,4-D e AIA induziram a formação de calos friáveis com setores pró-embriogênicos, refletindo a aquisição de competência morfogenética. Posteriormente foi observada a expressão do programa embriogênico quando massas próembriogências desenvolveram-se formando embriões somáticos. Esses resultados apresentam uma alternativa para a utilização de um tipo de explante que possibilita o cultivo in vitro de helicônia sem o desenvolvimento de bactérias endofíticas.

\section{REFERENCES}

Almeida, E. P. de; Oliveira, R. P. de. Dantas, J. L. L. (2001), Indução e desenvolvimento de calos e embriões somáticos em mamoeiro. Scientia Agrícola, Piracicaba, 58: (1), 51-54.

Atehortua, L.; Urrea, A. L.; Gil, U.; Mora, B.; Valencia, C.; Corrales, M.; Carmona, A.; Vallejo, A. (1999), Heliconia Tissue Culture. Bulletin of Heliconia Society International, 9: (4), 16-17.

Castro, C. E. F. de. (1995), Helicônia para exportação: Aspectos técnicos da produção. Brasília: (FRUPEX. Publicações Técnicas, 16). 44p.

Cruz, G. S.; Canhoto, J. M.; Abreu, M. A. V. (1990), Somatic embryogenesis and plant regeneration from zygotic embryos of Feijoa sellowiana Berg. Plant Science. Limerick, 66, 263-270.

Dias, M. A.; Rodrigues, P. H. V. (2001), Fontes de explantes e contaminantes isolados em cultivo in vitro de helicônia. Revista Brasileira de Horticultura Ornamental, Campinas. 7: (2), 165-168. 
Durzan, D. J. (1988), Somatic polyembryogenesis for the multiplication of tree crops. Biotecnology and Genetic Engineering Review, 6, 341-378.

Flores, R.; Peters, J. A.; Fortes, G. R. de L.; Oliveira, M. de F. (2003), Efeito de concentrações de 2.4-D, picloram e BAP na indução de calos e regeneração de plantas de morangueiro cv. Vila Nova. Revista Ciência Rural, Santa Maria, 8: (2), 87-91.

Franco, E. T. H.; Gavioli, L.B.; Ferreira, A. G. (2006) In vitro regeneration of Didymonopanax morototoni. Brazilian Journal Biology, 66(2A), 455-462.

Gaj, M. D. (2004), Factors influencing somatic embryogenesis induction and plant regeneration with particular reference to Arabidopsis thaliana (L.) Heynh. Plant Growth Regulation, 43: 27-47.

Goh, C. J.; Nathan, M. J.; Kumar, P. P. (1995), Direct organogenesis and induction of morphogenic callus through thin section culture of Heliconia psittacorum. Scientia Horticulturae, Amsterdam, 62, 113-120.

Guerra, M. P.; Torres, A. C.; Teixeira, J. B. (1999), Embriogênese somática e sementes sintéticas. In: Torres, A. C.; Caldas, L. S.; Buso. J. A. (Eds.). Cultura de tecidos e transformação genética de plantas. Brasília: EMBRAPA-SPI, 2, 533-568.

Hervé, P.; Jauneau, A.; Pâques, M.; Marien, J.; Boudet, A. M.; Teulières C. (2001), A procedure for shoot organogenesis in vitro from leaves and nodes of Eucalyptus gunnii clone: comparative histology. Plant Science, Limerick, 161, 645-653.

Hu, C. Y., Ferreira, A. G. (1998), Cultura de Embriões. In: A. C. Torres; L. S. Caldas; J. A. Buso (eds.). Cultura de tecidos e transformação genética de plantas. Brasília: EMBRAPA-SPI, 1, 371-393.

Inoue, T.; Higuchi, M.; Hashimoto, Y.; Seki, M.; Kobayashi, M.; Kato, T.; Tabata, S.; Shinozaki, K. Kakimoto, T. (2000), Identification of CRE1 as a cytokinin receptor from Arabidopsis. Nature, 409, 1060-1063.

Johansen, D.A. (1940), Plant microtechnique. McGrawHill, New York, 523p.

Kevers, C.; Gaspar, T.; Dommes, J. (2002). The beneficial role of different auxins and polyamines at successive stages of somatic embryo formation and development of Panax ginseng in vitro. Plant Cell, Tissue and Organ Culture, 70: 181-188.

Kim Y. W., Youn Y., Noh E. R.; Kim J. C. 1997. Somatic embryogenesis and plant regeneration from immature embryos of five families of Quercus acutissima. Plant Cell Reports, 16: 869-873.

Kim, S. W.; Oh, S. C.; In, D. S.; Liu, J. R. (2003), High frequency somatic embryogenesis and plant regeneration in zygotic embryo cultures of japanese honeysuckle. Plant Cell, Tissue and Organ Culture, Dordrecht, 72, 277-280.

Kurten, U.; Nautila, A. M.; Kauppinen, V.; Rousi, M. (1990), Somatic embryogenesis in cell cultures of birch (Betula pendula Roth.) Plant Cell Tissue and Organ Culture, Dordrecht, 23, 101-105.
Liu, C.; Xia, X.; Yin, W.; Huang, L.; Zhou, J. (2006), Shoot regeneration and somatic embryogeneis from needles of redwood (Sequoia sempervirens (D. Don.) Endl.). Plant Cell Reports, 25, 621-628.

Martini, P. C.; Willadino, L.; Alves, G. D.; Donato, V. M. T. S. (2001), Propagação de orquídea Gongora quinquenervis por semeadura in vitro. Pesquisa Agropecuária Brasileira, Brasília, 36: (10), 13191324.

Mathew, M. M.; Philip, V. J. (2003), Somatic embryogenesis versus zygotic embryogenesis in Ensete superbum. Plant Cell, Tissue and Organ Culture, Dordrecht, 72, 267-275.

Murashige, T.; Skoog, F. (1962), A revised medium for rapid growth and biossays with tobacco tissue culture. Physiologia Plantarum, Copenhagen, 15, 473-497.

Nathan, M. S.; Goh, C. J.; Kumar, P. P. (1992), In vitro propagation of Heliconia psittacorum by bud culture. Hortsience, Alexandria, 27, 450-452.

Nowak, J.; Shulaev, V. (2003), Priming for transplant stress resistance in in vitro propagation. In Vitro Cell. Development Biol. Plant, 39, 107-124.

Peres, L. E. P. (2002), Bases fisiológicas e genéticas da regeneração de plantas in vitro. Biotecnologia Ciência and Desenvolvimento, Brasília, n. 25, março/abril. 44-48.

Radojevic, L. (1979), Somatic embryos and plantles from callus cultures of Paulownia tomentosa Steud. Zeitschrift fur Pflanzenphysiol, 91. 57-62.

Rai, V. R.; Mccomb, J. (2002), Direct somatic embryogenesis from mature embryos of sandalwood. Plant Cell, Tissue and Organ Culture, Dordrecht, 69. 65-70.

Rodrigues, P. H. V. (2005), In vitro establishment of Heliconia rauliniana (HELICONIACEAE). Scientia Agricola, 62: 69-71.

Rodriguez, A. P. M.; Wetzstein, H. Y. (1998), A morphological and histological comparison of the initiation and development of pecan (Carya illinoinensis) somatic embryogenic cultures induced with naphthaleneacetic acid or 2.4-D dichlorophenoxyacetic acid. Protoplasma, New York, 204. 71-83.

Sáenz, L.; Azpeitia, B.; Chuc-Armendariz, B.; Chan, J. L.; Verdeil, J. L.; Hocher, V.; Oropeza, C. (2006), Morphological and histological changes during somatic embryo formation from coconut plumele explants. In vitro Cell. Dev. Biol. Plant. 42, 19-25.

Sakhanokho, H. F.; Ozias-akins, P.; May, O. L.; Chee, P. W. (2005), Putrescine enhances somatic and plant regeneration in upland cotton. Plant Cell Tissue Organ Culture, 81, 91-95.

Sondahl, M. R.; Salisbury, J.L.; Sharp, W. R. 1979. SEM characterization of embryogenic tissue and globular embryos during high frequency somatic embryogenesis in coffee callus cells. Zeitschrift fur Pflanzenphysiologie, 94, 185-188. 
Valencia, C.; Atehortua, L. (1999), Somatic embryogenesis in Heliconia stricta Huber. The Bulletin. May, p.14.

Yadav, J. S.; Rajam, M. V. (1998) Temporal Regulation of Somatic Embryogenesis by Adjusting Cellular Polyamine Content in Eggplant. Plant Physiology, 116: $617-625$.
Williams, E. G.; Maheswaran, G. (1986), Somatic embryogenesis: Factors influencing coordinated behavior of cells as an embryogenic group. Annals of Botany, London, 57, 443-462.

Zimmerman, J. L. (1993), Somatic embryogenesis: a model for early development in higher plants. The Plant Cell, 5, 1411-1423. 